\title{
PENGARUH PERSEPSI SISWA TERHADAP FAKTOR-FAKTOR YANG MEMPENGARUHI PRESTASI BELAJAR TEORI KEJURUAN SISWA SMK
}

\author{
Arwan Nur Ramadhan \\ Jurusan Pendidikan Administrasi FE UNY \\ arwan@prabuanomjati.web.id \\ Soenarto \\ Universitas Negeri Yogyakarta \\ soenarto@uny.ac.id
}

\begin{abstract}
Abstrak
Penelitian ini bertujuan untuk mengungkap: (1) persepsi siswa tentang kompetensi mengajar guru, pola asuh orang tua, motivasi berprestasi siswa, kelengkapan sarana prasarana praktik, dan prestasi belajar teori kejuruan; (2) pengaruh keempat variabel bebas secara sendiri-sendiri maupun bersamasama terhadap variabel terikat. Penelitian ini merupakan penelitian ex-post-facto, dilaksanakan di empat SMK se-Kabupaten Sleman. Populasi 205 siswa kelas XII Teknik Komputer dan Jaringan T.A 2014-2015. Teknik sampling menggunakan proportionate random sampling dan jumlah ditentukan berdasarkan tabel Krejcie \& Morgan. Teknik analisis data menggunakan analisis deskriptif dan regresi. Hasil penelitian menunjukkan bahwa persepsi siswa tentang: (1) kompetensi mengajar guru sangat tinggi; pola asuh orang tua rendah; motivasi berprestasi siswa rendah; kelengkapan sarana dan prasarana praktik sangat rendah; dan prestasi belajar teori kejuruan sangat rendah; (2) keempat variabel bebas masing-masing berpengaruh positif dan signifikan terhadap prestasi belajar teori kejuruan; dan secara bersama-sama berpengaruh positif dan signifikan dengan sumbangan 50,3\% sedangkan 49,7\% dijelaskan oleh variabel lain yang tidak diteliti.
\end{abstract}

Kata kunci: kompetensi mengajar guru, pola asuh orang tua, motivasi berprestasi peserta didik, kelengkapan sarana dan prasarana praktik, prestasi belajar teori kejuruan, Teknik Komputer dan Jaringan.

\section{THE EFFECTS OF STUDENT'S PERCEPTION OF FACTORS AFFECTING LEARNING ACHIEVEMENT OF VOCATIONAL THEORY ON STUDENT'S SMK}

\begin{abstract}
This study aims to reveal: (1) students' perception of teachers' teaching competency, parenting, students' achievement motivation, adequacy of facilities practium, and learning achievement in vocational theory; (2) the effect of four independent variables individually or together on dependent variables. This study is an ex-post-facto, implemented in four SMK's in Sleman Regency. The population was 205 students' of class XII of Computer Engineering and Networks in the Academic Year of 2014-2015. The sample was established using the proportionate random sampling technique and determined using Krejcie \& Morgan tables. The technique of data analysis used in this study included descriptive analysis and regression. The results show that students' perception: (1) the competency of the teachers'teaching is very high, parenting as low, achievement motivation students' as low, and adequacy of facilities practices as very low, students'learning achievement in vocational theory as very low; and (2) four independent variables each positive and significant impact on students' of the learning achievement in vocational theory; and together positive and significant with contribution $50.3 \%$ while $49 \%$ is explained by other variables outside in this research.
\end{abstract}

Keywords: teachers'teaching competence, parenting, students' achievement motivation, adequacy offacilities practices, learning achievement in vocational theory, Computer Engineering and Networks. 


\section{PENDAHULUAN}

Kemampuan berpikir kritis untuk memecahkan masalah, dan berkolaborasi diperlukan calon tenaga kerja lulusan pendidikan kejuruan untuk beradaptasi di abad 21. "Students must also learn the essential skills for success in today's world, such as critical thinking, problem solving, communication and collaboration" (P21 Framework Definitions, 2009, p.1). Kompetensi tersebut perlu ditanamkan sejak dini pada lulusan pendidikan kejuruan untuk mencetak tenaga kerja trampil siap kerja. Di tengah persaingan abad 21, Indonesia harus bersiap menghadapi pasar bebas atau ASEAN Economic Community 2015. Pembentukan pasar perdagangan bebas akan mendorong peningkatan efisiensi, daya saing, dan peluang penyerapan tenaga kerja seluruh Negara di kawasan Asia Tenggara. Indonesia harus menyiapkan tenaga kerja trampil dan terdidik untuk ikut bersaing dalam pasar bebas. Oleh karena itu, pelatihan dan pendidikan tenaga kerja perlu ditingkatkan baik pada pendidikan menengah maupun pendidikan tinggi.

Upaya peningkatan kualitas lembaga pendidikan dan pelatihan kejuruan masih dihadapkan berbagai permasalahan. Menurut Mohammad Nuh, Pikiran Rakyat Online, 2 April 2014, kurangnya tenaga kerja trampil, keterbatasan mendapatkan praktik pelatihan di sekolah, hingga harmonisasi regulasi sistem pelatihan dan pasar kerja merupakan permasalahan yang dihadapi pendidikan dan pelatihan kejuruan saat ini. Keterbatasan mendapatkan praktik pelatihan di sekolah kejuruan tidak terlepas dari ketersediaan sarana dan prasarana praktik sesuai bidang kejuruan.

Data Badan Pusat Statistik Agustus 2013 menunjukkan angka pengangguran lulusan pendidikan kejuruan dikategorikan tinggi. Data pengangguran terbuka lulusan SMK sejumlah 1,2 juta jiwa. Data tersebut mengalami peningkatan dari survey sebelumnya pada bulan Februari yaitu hanya mencapai 847 jiwa. Angka pengangguran tinggi menunjukkan bahwa keberterimaan lulusan SMK untuk bekerja masih rendah. Keberterimaan lulusan pendidikan kejuruan yang rendah di duga disebabkan kualitas kompetensi lulusan jauh dari harapan kebutuhan dunia kerja. Meskipun peluang kerja terbuka lebar, namun kualifikasi kompetensi kurang memadahi, maka berapapun jumlah lulusan pendidikan kejuruan tentu tidak akan mampu terserap dengan baik di tempat kerja.

Kualitas kompetensi calon lulusan pendidikan kejuruan dapat diukur melalui penilaian pembelajaran. Penilaian pembelajaran dilaksanakan oleh guru, sekolah dan pemerintah. Guru melakukan penilaian dalam bentuk ulangan harian yang dilaksanakan setelah mengajarkan kompetensi tertentu, sekolah melaksanakan penilaian secara periodik pada tengah dan/atau akhir semester, sedangkan pemerintah melakukan penilaian pada akhir tingkat pendidikan. Penilain yang dilakukan pemerintah pada dikenal dengan Ujian Nasional (UN). Pelaksanaan UN SMK khusus bidang keahlian disebut dengan Uji Kompetensi keahlian (UKK).

Berdasarkan hasil observasi di SMK Bina Harapan diketahui nilai UN produktif tahun ajaran 2013-2014 mengalami penurunan dibandingkan tahun sebelumnya. Tahun 20122013 nilai rata-rata UN produktif adalah 8,07 dan tahun 2013-2014 hanya 7,80; artinya mengalami penurunan sebesar 0,27 . Nilai terrendah juga mengalami penurunan dari 7,50 menjadi 6,61 pada tahun ajaran 2013-2014. Hal tersebut di duga disebabkan oleh nilai UN teori yang sangat rendah, nilai terendah yang dicapai siswa pada nilai UN teori adalah 1,50 dengan nilai rata-rata 5.25. Kondisi tersebut tentu sangat mempengaruhi perolehan UN produktif secara akumulatif.

Kondisi lain yang dapat diamati menunjukkan bahwa motivasi siswa untuk menguasai kompetensi sangat rendah. Siswa terlihat suka bermalas-malasan, lebih banyak bermain smartphone, sering datang terlambat, dan jarang mencatat materi yang disampaikan oleh guru. Kemampuan mengajar guru menjadi salah satu penyebab kondisi tersebut menjadi budaya di dalam kelas. Kebiasan beberapa guru yang sering meninggalkan kelas tanpa alasan, tidak memberikan materi sesuai dengan silabus, kurangnya pengawasan oleh guru piket saat jam kosong secara perlahan menjadi 
kebiasaan dan budaya sehingga peserta didik berperilaku menyimpang di sekolah.

Kondisi lain yang ditemui bahwa beberapa orang tua yang datang ke sekolah untuk membayar Sumbangan Pembinaan Pendidikan (SPP) tidak mengetahui informasi kondisi anak di sekolah, seperti informasi kelas dan jenjang yang ditempuh. Kondisi ini megindikasikan bahwa komunikasi anak dan orang tua kurang terjalin dengan baik. Selain itu, pada beberapa anak yang memiliki motivasi rendah diketahui bawah anak tersebut sangat kurang mendapatkan perhatian dari orang tua.

Prestasi belajar yang diraih peserta didik dapat menunjukkan kualitas pembelajaran pada lembaga pendidikan. Menurut Catts, Falk, \& Wallace $(2011$, p.208) bahwa kesuksesan lembaga pendidikan dalam menyelenggarakan pembelajaran dapat dilihat dari: (1) penguasaan kompetensi, (2) pencapaian prestasi akademik, (3) pencapaian prestasi kerja praktik, dan (4) kemampuan menyelesaikan pekerjaan yang diberikan. Oleh karena itu, peran aktif lembaga pendidikan untuk mengelola dan memfasilitasi kegiatan pembelajaran menjadi keharusan untuk menunjukkan kualitas kegiatan pembelajaran yang diselenggarakan.

Kontrol terhadap lingkungan sekolah dan lingkungan belajar membantu penguasaan kompetensi dan pencapaian prestasi siswa. Iklim yang terbentuk di lingkungan sekolah, menentukan motivasi siswa untuk berprestasi. Menurut Marzano \& Marzano (2003, p.6-8) interaksi antara guru dan siswa menjadi kunci pencapaian prestasi belajar siswa. Namun tidak sedikit guru yang hanya memberikan catatan dan tugas di kelas bahkan tidak masuk tanpa keterangan. Kondisi pembelajaran tersebut berdampak pada motivasi siswa untuk belajar dan berprestasi menjadi menurun.

Kemampuan guru memilih metode mengajar menjadi salah satu kunci kesuksesan pengelolaan kegiatan belajar mengajar. Briggs \& Sommefeldt (2002, p.92-93) berpendapat bahwa untuk menyelenggarakan kegiatan pembelajaran yang berkualitas, guru harus memiliki mempu melakukan planning, assessment, evaluation, dan monitoring. Tugas guru membuat perencanaan pembelajaran, penilaian, evaluasi dan pengawasan diperlukan agar pembelajaran yang diselenggarakan dapat berjalan dengan baik dan sistematis.

\section{Pendidikan Kejuruan}

Menurut Rojewski (2009, p.32) bahwa konsep pendidikan kejuruan sejak awal adalah menyediakan pendidikan dan pelatihan untuk kelas pekerja dengan keahlian secara spesifik. Hal senada juga disampaikan Sanders (Pavlova, 2009, p.5) "implicit conceptualisations of vocational education are related to skill in using tools and machines", artinya bahwa konsep pendidikan kejuruan selalu berhubungan dengan ketrampilan dalam menggunakan alat dan mesin.

Adhikary (Sudira, 2012, p.13) berpendapat bahwa pendidikan kejuruan adalah pendidikan yang dirancang untuk mengembangkan ketrampilan, kemampuan/kecakapan, pemahaman, sikap, kebiasaan-kebiasaan kerja, dan apresiasi yang diperlukan pekerja dalam memasuki pekerjaan dan membuat kemajuankemajuan dalam pekerjaan penuh makna dan produktif. Dijelaskan lebih lanjut oleh Sudira (2012, p.13) bahwa pendidikan kejuruan merupakan pendidikan menengah yang mempersiapkan peserta didik terutama untuk bekerja dalam bidang tertentu.

Dari berbagai pendapat di atas dapat disimpulkan bahwa pendidikan kejuruan adalah pendidikan yang dirancang untuk membekali, melatih, mengembangkan pemahaman teori, ketrampilan praktik, dan sikap kerja lulusan yang baik. Dengan bekal tersebut, lulusan pendidikan kejuruan mampu mengoperasikan alat sesuai bidang keahlian dan memiliki etos kerja yang baik sehingga mampu bekerja dan bertahan hidup.

\section{Kompetensi Mengajar Guru}

Klusmann (2013, p.294) menjelaskan bahwa "competence is defined as the personal capacity to successfully cope with specific demands". Kompetensi merupakan kemampuan yang ditunjukkan seseorang untuk mampu menyelesaikan pekerjaan sesuai profesi yang ditekuni. Kompetensi erat kaitannya dengan unjuk kerja. Menurut Campbell (Koopmans, 2011, p.858) bahwa "task performance can be defined as the 
proficience (ie, competency) with which one performs central job tasks", artinya bahwa ukuran kompetensi dapat ditunjukkan dari kemampuan seseorang menyelesaikan tugas pekerjaan sehari-hari.

Mengajar merupakan bagian dari proses penyampaian informasi pada kegiatan pembelajaran. Kember (Norton, 2009, p.6) menjelaskan "conceptions of teaching are commonly found to fall into two main categories: teaching as information transmission and teaching as supporting students' learning". Bahwa konsep mengajar terdiri dari dua kategori utama yaitu mengajar sebagai transfer ilmu dan mengajar sebagai pendukung bagi peserta didik dalam belajar. Menurut Smith (1998, p.68) "In teaching we build on the learner's prior knowledge and models of understanding irrespective of whether these are formally 'correct' or 'incorrect'”. Mengajar adalah membangun pengetahuan dan pemahaman kepada peserta didik secara formal untuk dapat menentukan benar dan salah.

Mengajar bukan hanya sekedar proses menyajikan materi, tetapi juga membutuhkan ketrampilan guru yang sistematis dan kreatif untuk mencapai hasil pembelajaran yang baik. Griffin et.al (Nasrudin \& Khuan, 2007, p.338) berpendapat “...performance was evaluated in terms of the proficiency with which an individual carried out the tasks that were prescribed in his or her role descriptions". Kinerja merupakan hasil evaluasi kemampuan individu dalam menyelesaikan tugas utama sesuai dengan profesi sehari-hari. Tugas utama guru adalah mengajar, sehingga kompetensi guru dapat dilihat salah satunya dari kemampuan guru dalam mengajar.

Dijelaskan lebih lanjut oleh Briggs \& Sommefeldt bahwa untuk menyelenggarakan kegiatan pembelajaran yang berkualitas, guru harus memenuhi empat kriteria yaitu: planning, assessment, evaluation, dan monitoring. Kemampuan guru dalam merencanakan, menilai, mengevaluasi dan memonitor setiap kegiatan pembelajaran akan menjadi kunci keberhasilan dalam mengelola pembelajaran. Selain itu, guru juga harus sehat secara jasmani dan rohani serta memenuhi syarat kualifikasi akademik yang diperoleh melalui pendidikan tinggi program sarjana atau diploma empat.

\section{Pola Asuh Orang Tua}

Lollis \&Kuczynksi (Grolnick, Friendly, \&Bellas, 2009, p.294) mendefinisikan mengasuh sebagai sebuah proses yang terjadi dua arah di mana anak adalah active participants dalam lingkungan pengasuhan. Proses pembelajaran pertama pada anak terjadi di dalam keluarga. Interaksi antara orang tua dan anak dalam keluarga akan membentuk pola komunikasi yang baik. Komunikasi yang baik dengan orang tua dapat membentuk pola komunikasi yang baik pula dengan orang lain.

Dampak pola komunikasi dalam mengasuh antara orang tua dengan anak juga disampaikan Bornstein (2008, p.266) "parenting is defined in terms of its propensity to move children toward those goals that the culture deems important". Mengasuh selalu memiliki kecenderungan untuk mendorong dan mengajak anak agar memiliki kebiasaan dan budaya yang baik. Mengasuh merupakan sebuah kegiatan yang sangat kompleks mengacu pada perilaku oleh kedua orang tua dalam membentuk karakter anak (Darling, 1999, p.1).

Krause \& Dailey (2009, p.1) berpendapat bahwa "this parenting style involves a combination of affection and attentive responsiveness to children's needs, along with clear, firm expectations for developmentally appropriate, socially responsible behavior", pola asuh orang tua adalah kombinasi dari kasih sayang dan perhatian secara responsif sesuai kebutuhan perkembangan anak. Seorang pengasuh harus mampu menemukan keseimbangan terhadap pemenuhan kebutuhan sesuai dengan usia perkembangan anak (Vazquez, 2004, p.144).

Temuan dasar dari penelitian yang dilakukan oleh Diana Baumrind (Ramaekers \& Suisca, 2012, p.76) mengidentifikasi tiga bentuk pola asuh orang yaitu: authoritarian, authoritative, dan permissive (indulgent). Diana Baumrind menambahkan pola yang keempat yaitu neglectful or uninvolved. Dijelaskan bahwa pola asuh neglectful bukan merupakan gaya atau bentuk pola asuh orang tua melainkan merupakan sebuah sikap pembiaran dari orang tua. 
Maccoby \&Martin (Rothrauff, Cooney, \& An, 2009, p.138) membagi bentuk pola asuh orang tua menjadi empat yaitu: authoritative, authoritarian, indulgent, dan uninvolment. Berdasarkan empat model pola asuh orang tua tersebut, Gracia \& Gracia (2009, p.102) mengelompokkan menjadi dua dimensi hubungan sosial orang tua yaitu responsiveness dan demandingness. Pola asuh responsiveness mengacu pada pengasuhan yang hangat dan memberikan dukungan dimana orang tua menawarkan apa yang diinginkan dan dituntut oleh anak. Sedangkan demandingness mengacu pada kontrol tingkah laku anak, orang tua membesarkan anak dengan memberikan tuntutan, pengawasan, disiplin yang harus ditaati.

\section{Motivasi Berprestasi Peserta Didik}

Setiap individu membutuhkan motivasi dan tujuan dalam berkarya dan berperilaku dalam kehidupan sehiari-hari. Menurut Brophy (2004, p.3-4) "motivation is a theoretical construct used to explain the initiation, direction, intensity, persistence, and quality of behavior, especially goal-directed behavior". Motivasi berkaitan dengan inisiasi, arah, intensitas, ketekunan, dan perilaku seseorang dalam mencapai tujuan. Motivasi akan membentuk pola tingkah laku dan menentukan arah melangkah setiap individu dalam berperilaku.

Kebutuhan akan berbagai hal dalam hidup manusia menjadi sebuah motivasi untuk melakukan perbuatan. Di mana perbuatan yang diambil merupakan usaha manusia untuk bertahan hidup dan mendapatkan apresiasi tertinggi dalam hidup. Moslow (1970, p.xii) menjelaskan bahwa kecenderungan manusia adalah untuk growth, self-actualization, the striving toward health, the quest for identity and autonomy, dan the yearning for excellence. Kecenderungan manusia adalah untuk menjadi pribadi yang unggul dan hal itu mendorong manusia untuk berprestasi.

Menurut Nicholls (Wigfield \& Eccles, 2002, p.1) "achievement motivation refers to motivation in situations in which individuals competence is at issue", bahwa motivasi berprestasi muncul pada diri seseorang di mana penguasaan kompetensi merupakan tujuan utama. Eccless, WIgfield \& Schiefele (Wigfield \& Eccles, 2002, p.1) menjelaskan "achievement motivation theorists attempt to explain people's choice of achievement tasks, persistence on those tasks, vigor in carrying them out, and quality of task engagement", motivasi berprestasi merupakan pilihan seseorang untuk memiliki kompetensi tertentu secara persisten, bersemangat, dan menunjukkan kualitas penyelesaian tugas dengan baik. Menurut Hill (1980, p.42) motivasi berprestasi merupakan dorongan yang muncul pada diri seseorang untuk mendekati kesuksesan. Menurut Atkinson (1980, p.9) "achievement motivation is the way in which it is changing our ideas about how motivation influences behavior", di mana setiap individu yang memiliki motivasi berprestasi maka individu tersebut akan mampu menentukan arah melangkah.

Clifford (1980, p.105) menjelaskan bahwa motivasi berprestasi terkait dengan reaksi seseorang terhadap kegagalan dan keberhasilan yaitu motivasi untuk berhasil dan menghindari kegagalan. Kecenderungan terhadap keberhasilan dan kegagalan mencapai prestasi juga mendorong peserta didik untuk giat dalam belajar. Dweck (Hewit, 2008, p.32) mengidentifikasi motivasi belajar yaitu: performance orientated learning yang berorientasi pada hasil yang memuaskan dalam menyelesaikan tugas dan mastery orientated learning yang berorientasi pada penguasaan materi pembelajaran.

Motivasi berprestasi dapat dikatakan merupakan sebuah dorongan untuk terus berusaha meningkatkan atau tetap mempertahankan prestasi yang telah diraih. Setiap individu akan terus berusaha untuk mencapai standar atau kriteria ketuntasan yang telah ditetapkan meskipun belum dapat dipastikan bahwa usaha yang dilakukan akan berhasil atau gagal. Namun setiap individu akan berusaha sebaik mungkin untuk mencapai prestasi yang diinginkan. Rintangan dalam mencapai prestasi menjadi tantangan bagi setiap individu untuk berusaha mencapai cita-cita yang diinginkan.

Salah satu indikator dalam motivasi berprestasi yaitu munculnya dorongan untuk memaksimalkan peluang keberhasilan dan 
meminimalkan peluang kegagalan. Menurut Pang (2010, p.35) "Motivated achievement behavior can be categorized as approach tendencies, which are when people are driven to maximize the chances of succeeding at the achievement task, and avoidance tendencies, which are when people are driven to minimize the chances of failing the task". Perilaku peserta didik yang termotivasi untuk berprestasi kecenderungan memiliki dorongan untuk memaksimalkan peluang keberhasilan menyelesaikan tugas. Perilaku lain yaitu kecenderungan menghindari kegagalan dengan meminimalkan peluang-peluang yang berpotensi mengagalkan tugas yang diberikan.

\section{Kelengkapan Sarana dan Prasarana Praktik}

Menurut Mulyasa (2002, p.49) sarana pendidikan adalah peralatan dan perlengkapan yang secara langsung dipergunakan dan menunjang proses pendidikan, khususnya proses belajar mengajar, sepeti gedung, ruang kelas, meja kursi, serta alat-alat dan media pembelajaran. Pendapat lain disampaikan oleh Sanjaya (2006, p.53) bahwa sarana adalah segala sesuatu yang mendukung langsung terhadap kelancaran proses pembelajaran, misalnya media pembelajaran, alat-alat pelajaran, perlengkapan sekolah dan lain sebagainya.

Slameto (2003, p.6) menjelaskan bahwa alat pelajaran memiliki hubungan yang erat dengan cara belajar peserta didik karena alat pelajaran yang dipakai oleh guru pada waktu mengajar dipakai pula oleh peserta didik untuk menerima bahan yang diajarkan itu. Alat pelajaran yang lengkap dan tepat akan memperlancar peserta didik dalam menerima materi dan bahan pelajaran dari guru. Dalam Peraturan Menteri Pendidikan Nomor 40 Tahun 2008 menjelaskan bahwa sarana adalah perlengkapan yang dapat dipindah-pindah.

Dari uraian pendapat di atas, dapat disimpulkan bahwa sarana pembelajaran merupakan peralatan dan perlengkapan yang bersifat dinamis dan mendukung kelancaran kegiatan pembelajaran yang diselenggarakan. Sarana pembelajaran dipergunakan oleh guru dalam menggambarkan dan mendemonstrasikan teori yang disampaikan agar lebih mudah untuk diterima.
Paradigma teacher centered di mana guru mendominasi pembelajaran di depan kelas mulai digantikan dengan student centered dimana keaktifan peserta didik menjadi kunci dalam pembelajaran. Pemanfaatan media pembelajaran interaktif sebagai salah satu sarana pendukung pembelajaran tentu akan mendorong peserta didik dalam berperan aktif dalam kegiatan pembelajaran.

Keberadaan sarana pembelajaran tentu tidak dapat dipisahkan dari prasarana sebagai komponen pelengkap dalam fasilitas pembelajaran yang ada di sekolah. Mulyasa (2002, p.49) berpendapat bahwa prasarana pendidikan adalah fasilitas yang secara tidak langsung menujang jalannya proses pendidikan atau pembelajaran, seperti halaman, kebun, taman sekolah dan jalan menuju sekolah. Namun jika taman sekolah dimanfaatkan untuk pengajaran biologi, halaman sekolah sekaligus sebagai lapangan olah raga maka komponen tersebut merupakan sarana pendidikan. Pendapat yang senada disampaikan oleh Sanjaya (2006, p.53) prasarana adalah segala sesuatu yang secara tidak langsung dapat mendukung keberhasilan proses pembelajaran, misalnya jalan menuju sekolah, penerangan sekolah, kamar kecil, dan lain sebagainya. Dalam Peraturan Menteri Pendidikan Nomor 40 Tahun 2008 mendefinisikan prasarana adalah fasilitas dasar untuk menjalankan fungsi SMK/MAK.

Dapat disimpulkan bahwa prasarana pembelajaran merupakan fasilitas sekolah yang bersifat statis dan sengajar disediakan oleh sekolah dalam rangka mendukung kelancaran proses pembelajaran yang disediakan. Keberadaan prasarana pembelajaran di sekolah menjadi pelengkap sarana pembelajaran dimana tujuan utama ketersediaan sarana dan prasarana adalah untuk menunjang kegiatan pembelajaran yang sedang dan akan diselenggarakan.

Kelengkapan sarana dan prasarana pembelajaran dalam pendidikan kejuruan merupakan hal yang wajib dipenuhi. Tujuan pendidikan kejuruan adalah untuk mempersiapkan peserta didik untuk siap berkerja dan menghadapi tantangan pengembangan kompetensi di tempat kerja 
untuk dapat bertahan hidup. Pengembangan kompetensi peserta didik sangat diperlukan ketersediaan alat dan bahan yang mendekati kondisi nyata di industri.

Dijelaskan oleh Erthman (2009, p.78) "there are many rules, regulations, and procedures imbedded in the school board policies that deal directly with the process of school facility planning", artinya bahwa banyak regulasi yang harus dipenuhi untuk menyediakan sarana dan prasarana dalam pada setiap sekolah untuk dapat menyelenggarakan setiap kegiatan pembelajaran sesuai dengan tuntutan kurikulum yang ada.

\section{Prestasi Belajar Teori Kejuruan}

Prestasi belajar menunjukkan tingkat penguasaan kompetensi peserta didik dari berbagai rangkaian aktivitas pembelajaran yang telah dilakukan. Menurut Pavlova (2009, p.142) "the outcomes of learning will be mainly formulated through patterns of activities and the fulfilment of tasks by students as the real indicators of student achievement", bahwa prestasi belajar merupakan representasi dari kegiatan pembelajaran yang dapat ditinjau dari berbagai pola aktivitas dan tugas-tugas yang telah diselesaikan oleh peserta didik. Definisi lain tentang prestasi dapat ditemukan dalam Dictionary of Education (Cizek, 1997, p.4) mendefinisikan prestasi: (1) accomplishment or proficiency of performance in a given skill or body of knowledge, (2) progress in school. Prestasi menggambarkan hasil pencapaian kinerja atau ketrampilan yang dimiliki yang merupakan hasil dari proses pembelajaran di sekolah.

Prestasi belajar merupakan gambaran pencapaian kompetensi peserta didik selama proses pembelajaran. Menurut Fyans (1980, p.51) "achievement is what student have in fact achieved", bahwa prestasi menunjukkan apa yang telah dicapai oleh peserta didik. Ditambahkan oleh Marzano \& Brown (2009, p.157) bahwa komponen kunci dalam pencapaian prestasi belajar adalah memastikan semua peserta didik secara intelektual, emosional dan sosial terukur dari apa yang telah dipelajari.

Pandangan senada disampaikan Liu \& Yu (2011, p.108) "learning achievements actually result from an interaction between cognitive, affective, and conative aspects". ketika prestasi belajar dapat terukur dengan akurat maka benar-benar akan dapat menggambarkan pencapaian kompetensi, tidak hanya pada kemampuan intelektual/kognitif saja, tetapi juga pada kemampuan berperilaku dalam sosial kemasyarakatan dan aspek konatif yaitu perilaku yang berhubungan dengan motivasi/ dorongan untuk memenuhi kebutuhan dalam kehidupan sosial kemasyarakatan.

\section{METODE PENELITIAN}

\section{Jenis Penelitian}

Penelitian ini menggunakan pendekatan kualitatif dengan jenis penelitian expost facto.

\section{Waktu dan Tempat Penelitian}

Jumlah SMK di Kabupaten Sleman terdata 58 SMK, 8 SMK Negeri dan 50 SMK Swasta dengan berbagai kompetensi keahlian. Dari 58 SMK, 9 SMK mengelola Kompetensi Keahlian Teknik Komputer dan Jaringan. Penentuan lokasi SMK sebagai objek penelitian dipilih dengan pertimbangan rasio SMK swasta dan negeri, dan representatif keterwakilan sekolah berdasarkan letak geografis. Penentuan objek penelitian menggunakan teknik cluster sampling. Berdasarkan teknis sampling tersebut ditentukan empat lokasi penelitian yaitu: SMK Negeri 2 Depok mewakili Sleman Tengah, SMK Muhammadiyah 1 Moyudan mewakili Sleman Barat, SMK Nasional Berbah mewakili Sleman Timur, SMK Bina Harapan Ngaglik mewakili Sleman Utara, dan tidak ada sekolah yang mewakili lokasi Sleman Selatan karena tidak ada sekolah SMK yang berlokasi di daerah tersebut. Penelitian ini dilaksanakan mulai tanggal 8 Agustus 2014 sampai dengan 23 Januari 2015.

\section{Target/Subjek Penelitian}

Subjek penelitian adalah semua siswa kelas XII Teknik Komputer dan Jaringan di empat SMK yang dapat dilihat pada Tabel 1.

Diketahui bahwa populasi penelitian ini berjumlah 205 peserta didik Kelas XII Kompetensi Keahlian Teknik Komputer dan Jaringan Tahun Pelajaran 2014-2015. 
Tabel 1. Populasi Penelitian

\begin{tabular}{llcc}
\hline No & Nama Sekolah & Populasi & Sampel \\
\hline 1. & SMK N 2 Depok & 62 & 41 \\
2. & SMK Muh. 1 Moyudan & 68 & 44 \\
3. & SMK Nasional & 34 & 22 \\
4. & SMK Bina Harapan & 41 & 27 \\
& Jumlah & 205 & 134 \\
\hline
\end{tabular}

Berdasarkan tabel Krejcie \& Morgan (Isaac \& Michael, 1982, p.193) diperoleh sampel 134 peserta didik. Penentuan sampel penelitian pada masing-masing sekolah menggunakan teknik proportionate random sampling di mana semua subjek penelitian mempunyai peluang untuk terambil menjadi anggota sampel penelitian secara acak dan proporsioanal.

\section{Prosedur}

Dalam penelitian ini terdapat lima variabel bebas dan satu variabel terikat yaitu: Kompetensi Mengajar Guru ( $\left.\mathrm{X}_{1}\right)$, Pola Asuh Orang Tua $\left(\mathrm{X}_{2}\right)$, Motivasi Berprestasi Peserta Didik $\left(\mathrm{X}_{3}\right)$, Kelengkapan Sarana dan Prasarana Praktik $\left(\mathrm{X}_{4}\right)$, dan Prestasi Belajar Teori Kejuruan $(\mathrm{Y})$ yang dapat digambarkan pada Gambar 1 berikut ini:

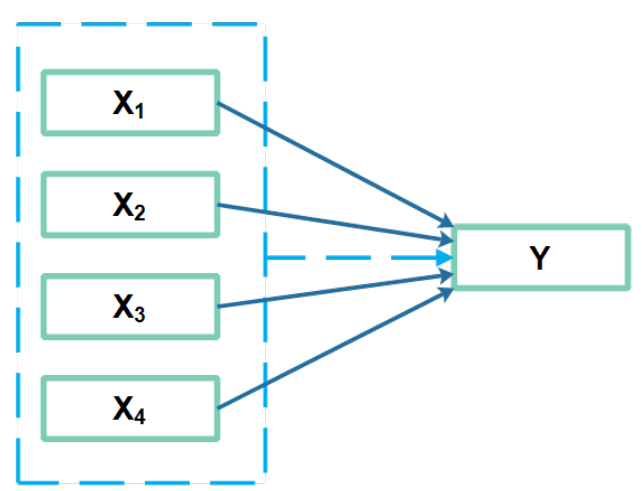

Gambar 1. Pengaruh $\mathrm{X}_{1} \mathrm{X}_{2} \mathrm{X}_{3} \mathrm{X}_{4}$ terhadap $\mathrm{Y}$

Untuk memperoleh gambaran yang tepat diperlukan batasan operasional pada masingmasing variabel sebagai berikut:

\section{Kompetensi Mengajar Guru}

Kompetensi mengajar guru merupakan pengetahuan, ketrampilan, dan perilaku yang diaplikasikan untuk menjalankan tugas mendidik, mengajar, membimbing, mengarahkan, melatih, menilai, dan mengevaluasi peserta didik. Kompetensi mengajar guru yang dimaksud adalah kompetensi guru dalam mengajar, mengelola kelas, dan berinteraksi dengan peserta didik.

\section{Pola Asuh Orang Tua}

Keterlibatan orang tua dalam suasana emosional membangun interaksi antara orang tua dan anak. Orang tua yang mampu berinteraksi, mengerti, dan memenuhi kebutuhan anak secara bijak dapat membentuk mental kepribadian anak dengan baik. Pola asuh orang tua digolongkan dalam empat yaitu: otoriter, otoritatif/demokratis, permisif, dan pembiaran. Variabel pola asuh orang tua menjelaskan seberapa demokratis orang tua dalam mengasuh anak.

\section{Motivasi Berprestasi Peserta Didik}

Motivasi merupakan daya dorong pada setiap individu untuk berperilaku. Salah satu motivasi yang ada pada diri setiap individu adalah motivasi berprestasi. Motivasi berprestasi merupakan keinginan atau daya dorong dari setiap individu untuk menghindari kegagalan, mencapai kesuksesan, dan mempertahankan kesuksesan yang telah diraih. Usaha yang dilakukan untuk mencapai kesuksesan dapat dilakukan dengan giat belajar, berusaha menguasai semua materi pelajaran, dan menyelesaikan tugas-tugas yang diberikan dengan baik.

\section{Kelengkapan Sarana dan Prasarana Praktik}

Kelengkapan sarana dan prasarana merupakan salah satu syarat terselenggarakannya pembelajaran di SMK. Sarana dan prasarana praktik merupakan peralatan dan perlengkapan yang bersifat dinamis dan mendukung kelancaran kegiatan pembelajaran yang diselenggarakan. Sarana pembelajaran dipergunakan oleh guru dalam menggambarkan 
Tabel 2. Klasifikasi Skor Daya Beda

\begin{tabular}{ll}
\hline Kondisi & Status \\
\hline $\mathrm{D} \geq 0,40$ & The item is functioning quite satisfactorily \\
$0,30 \leq \mathrm{D} \leq 0,39$ & Little or no revision is required \\
$0,20 \leq \mathrm{D} \leq 0,29$ & The item is marginal and needs revision \\
$\mathrm{D} \leq 0,19$ & The item should be eliminated or completely revised \\
\hline
\end{tabular}

dan mendemonstrasikan materi agar lebih mudah diterima, sedangkan prasarana pembelajaran merupakan fasilitas sekolah yang bersifat statis dan sengaja disediakan oleh sekolah untuk mendukung kelancaran proses pembelajaran. Kelengkapan sarana dan prasarana praktik ditinjau dari segi jumlah, kesesuaian jenis, kondisi/kualitas, pemakaian, dan ketersediaan peralatan praktik.

\section{Prestasi Belajar Teori Kejuruan}

Prestasi belajar teori kejuruan merupakan hasil belajar yang menggambarkan kemampuan kognitif peserta didik selama mengikuti pembelajaran produktif. Gambaran kemampuan peserta didik diperoleh dengan melakukan tes teori. Kisi-kisi yang digunakan diadaptasi dari kisi-kisi ujian nasional teori kejuruan.

\section{Data, Intrumen, dan Teknik Pengumpulan Data}

Pengumpulan data dilakukan dengan angket, observasi lapangan, dan tes. Angket digunakan untuk mengumpulkan data tentang kompetensi mengajar guru, pola asuh orang tua, motivasi berprestasi peserta didik, dan kelengkapan sarana dan prasarana praktik. Observasi lapangan dilakukan sebagai bahan cross check terkait kelengkapan sarana dan prasarana praktik di sekolah. Data prestasi belajar teori kejuruan diperoleh dengan tes teori. Jenis tes tertulis menggunakan soal pilihan ganda dengan lima alternatif pilihan jawaban.

Validitas instrumen menunjukkan sejauh mana suatu instrumen mampu mengukur secara tepat variabel penelitian. Validitas instrumen yang digunakan dalam penelitian ini adalah validitas isi dan validitas konstruk. Validasi isi dilakukan dengan cara membuat kisi-kisi dan dikonsultasikan kepada ahli (expert judgment) untuk menilai apakah butir-butir pertanyaan dapat mengukur aspek yang diteliti.
Validitas konstrak dilakukan dengan uji empirik melalui analisis faktor, yaitu mengkorelasikan item instrumen dengan variabel penelitian, selanjutnya dihitung dengan ujit. Apabila $t_{\text {hitung }}>t_{\text {tabel }}$ maka item dalam instrumen dinyatakan valid, dan sebaliknya jika $t_{\text {hitung }}<t_{\text {tabel }}$ maka item instrumen dinyatakan tidak valid (Riduwan, 2011, p.97101).

Validitas instrumen tes teori dilakukan dengan analisis butir menggunakan pendekatan teori klasik yaitu: (1) mengukur tingkat kesukaran butir soal, (2) daya beda, dan (3) kualitas pengecoh/distraktor (Allen \& Yen, 1979, p.123). Skor tingkat kesukaran butir soal yang dapat diterima adalah 0,3 sampai dengan 0,7 (Allen \& Yen, 1979, p.121).

Daya beda berguna untuk mengetahui sejauh mana butir soal mampu membedakan kemampuan peserta didik dalam menguasai materi dengan besaran antara 0,00 sampai dengan 1,00 (Crocker \& Algina, 2006, p.314315). Kriteria daya beda diklasifikasikan pada Tabel 2

Berdasarkan Tabel 2 tersebut, diperoleh informasi bahwa skor daya beda yang diterima adalah diatas 0,3 . Selain itu, diperlukan informasi tentang keberfungsian distraktor. Butir soal dianggap baik apabila dipilih secara merata oleh peserta didik dan mendekati jumlah ideal secara merata. Pengecoh dikatakan berfungsi dengan baik bila masingmasing alternatif jawaban dipilih minimal 5\% dari seluruh peserta tes.

\section{Teknik Analisis Data}

Teknik analisis menggunakan analisis deskriptif dan inferensial menggunakan regresi. Analisis deskriptif digunakan untuk mengetahui gambaran persepsi peserta didik tentang kompetensi mengajar guru, pola asuh orang tua, motivasi berprestasi, keleng- 
kapan sarana dan prasarana praktik, dan prestasi belajar teori kejuruan. Sedangkan analisis regresi digunakan untuk mengetahui bagaimana pengaruh persepsi peserta didik terhadap kompetensi mengajar guru, pola asuh orang tua, motivasi berprestasi peserta didik, dan kelengkapan sarana dan prasarana praktik secara sendiri-sendiri maupun bersama-sama terhadap prestasi belajar teori kejuruan peserta didik.

Sebelum dilakukan analisis regresi, terlebih dahulu dilakukan uji prasyarat analisis yaitu: (1) uji normalitas dengan uji One Sample Kolmogorov-Smirnov; (2) uji linearitas dengan melakukan Test for Linearity; (3) uji multikolinieritas dengan melihat nilai tolerance dan Variance Inflation Factor (VIF); dan (4) uji homosedatisitas dengan uji Glejser.

\section{HASIL PENELITIAN DAN PEMBAHASAN}

\section{Hasil Analisis Deskriptif}

Hasil analisis deskriptif pada variabelvariabel penelitian dijelaskan sebagai berikut:

\section{Kompetensi Mengajar Guru}

Butir pernyataan instrumen kompetensi mengajar guru terdiri dari 31 butir dan 1 butir dinyatakan tidak valid yaitu nomor 12 . Hasil Analisis deskriptif diperoleh rentang skor 90 s.d. 142; Mean (M) sebesar 121,87; Median (Me) sebesar 123,50; Modus (Mo) sebesar 124,00; Simpangan Baku (SB) sebesar 11,984; Mean ideal (Mi) sebesar 116; dan Simpangan Baku ideal (SBi) sebesar 8,67. Berdasarkan deskripsi data tersebut dapat diketahui gambaran persepsi peserta didik terhadap kompetensi mengajar guru seperti pada Gambar 2.

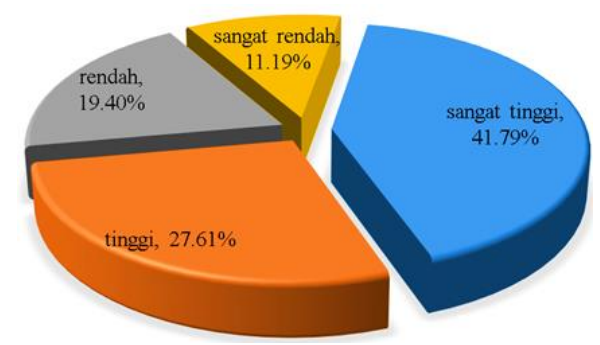

Gambar 2. Kompetensi Mengajar Guru

\section{Pola Asuh Orang Tua}

Butir pernyataan instrumen pola asuh orang tua terdiri dari 23 butir dan 1 butir dinyatakan tidak valid yaitu nomor 19 . Hasil Analisis deskriptif diperoleh rentang skor 62 s.d. 94; Mean (M) sebesar 76,99; Median (Me) sebesar 76,00; Modus (Mo) sebesar 74,00; Simpangan Baku (SB) sebesar 6,911; Mean ideal (Mi) sebesar 78,00; dan Simpangan Baku ideal (SBi) sebesar 5,33. Berdasarkan deskripsi data tersebut dapat diketahui gambaran persepsi peserta didik terhadap pola asuh orang tua seperti pada Gambar 3 berikut:

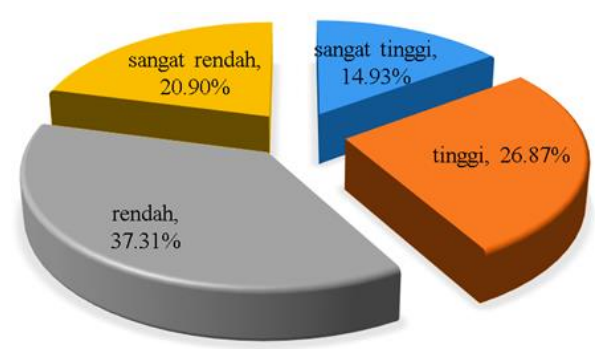

Gambar 3. Pola Asuh Orang Tua

\section{Motivasi Berprestasi Peserta Didik}

Butir pernyataan instrumen motivasi berprestasi peserta didik terdiri dari 25 butir dan semua butir dinyatakan valid. Hasil analisis deskriptif diperoleh rentang skor 68 s.d. 111; Mean (M) sebesar 91,83; Median (Me) sebesar 91,00; Modus (Mo) sebesar 88,00; Simpangan Baku (SB) sebesar 10,130; Mean ideal (Mi) sebesar 89,50; dan Simpangan Baku ideal (SBi) sebesar 7,17. Berdasarkan deskripsi data tersebut dapat diketahui gambaran motivasi berprestasi peserta didik seperti pada Gambar 4.

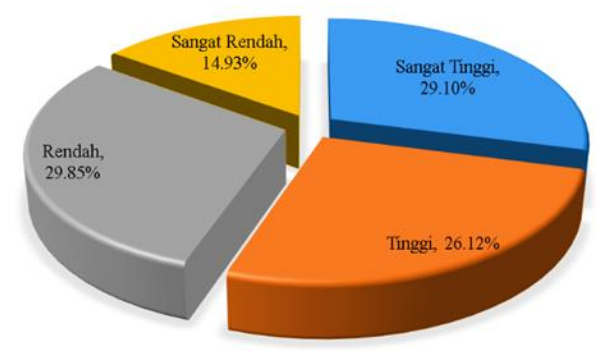

Gambar 4. Motivasi Berprestasi Peserta Didik

\section{Kelengkapan Sarana dan Prasarana Praktik}

Butir pernyataan instrumen kelengkapan sarana dan prasarana praktik terdiri dari 
39 butir dan semua dinyatakan valid. Hasil Analisis deskriptif diperoleh rentang skor 172 s.d. 193; Mean (M) sebesar 181,09; Median (Me) sebesar 181,00; Modus (Mo) sebesar 181,00; Simpangan Baku (SB) sebesar 4,680; Mean ideal (Mi) sebesar 182,50; dan Simpangan Baku ideal (SBi) sebesar 3,50. Berdasarkan deskripsi data tersebut dapat diketahui gambaran persepsi peserta didik terhadap kelengkapan sarana dan prasarana praktik seperti pada Gambar 5 berikut:

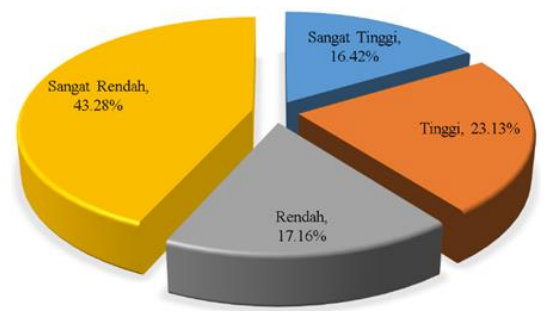

Gambar 5. Kelengkapan Sarana dan Prasarana

\section{Prestasi Belajar Teori Kejuruan}

Butir pernyataan instrumen prestasi belajar teori kejuruan terdiri dari 40 butir pertanyaan, 3 butir dinyatakan tidak valid yaitu nomor 2 , 14, dan 37. Hasil analisis deskriptif diperoleh rentang skor 40,54 s.d. 81,08; Mean (M) sebesar 59,37; Median (Me) sebesar 59,46; Modus (Mo) sebesar 59,46; Simpangan Baku (SB) sebesar 9,432; Mean ideal (Mi) 60,81; dan Simpangan Baku ideal (SBi) sebesar 6,76. Berdasarkan deskripsi data tersebut dapat diketahui gambaran prestasi belajar teori kejuruan peserta didik seperti pada Gambar 6 berikut:

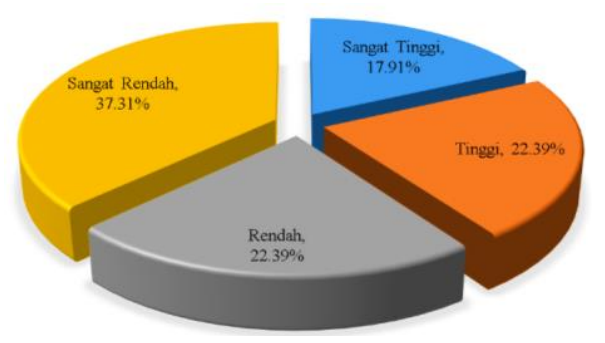

Gambar 6. Prestasi Belajar Teori Kejuruan

\section{Analisis Regresi}

Uji prasyarat analisis dilakukan sebelum analisis regresi yaitu uji : normalitas, linearitas, multikolinearitas, dan homosedastisitas dengan hasil sebagai berikut:
Tabel 3. Hasil Uji Normalitas Data

\begin{tabular}{ccc}
\hline Variabel & Asymp. Sig & Ket. \\
\hline X1 & 0,105 & Normal \\
X2 & 0,202 & Normal \\
X3 & 0,506 & Normal \\
X4 & 0,103 & Normal \\
Y & 0,191 & Normal \\
\hline
\end{tabular}

Kriteria pengambilan keputusan adalah jika nilai signifikansi Asymp. Sig (2-tailed) menunjukkan nilai lebih dari 0,05 maka data dapat dikatakan berdistribusi normal, sebaliknya jika nilai signifikansi Asymp. Sig (2-tailed) kurang dari 0,05 maka data berdistribusi tidak normal.

Tabel 4. Hasil Uji Linearitas Data

\begin{tabular}{ccc}
\hline Variabel & Linearity & $\begin{array}{c}\text { Defiation from } \\
\text { Linearity }\end{array}$ \\
\hline X1 & 0,000 & 0,659 \\
X2 & 0,000 & 0,135 \\
X3 & 0,000 & 0,211 \\
X4 & 0,000 & 0,655 \\
Y & 0,000 & 0,659 \\
\hline
\end{tabular}

Berdasarkan hasil Test for Linearity pada Tabel 4 diatas diketahui bahwa variabel bebas memiliki hubungan yang linear dengan variabel terikat karena nilai linearity kurang dari 0,05 dan nilai deviation from linearity lebih dari 0,05 .

Tabel 5. Hasil Uji Multikolinearitas Data

\begin{tabular}{ccc}
\hline Variabel & tolerance & VIF \\
\hline X1 & 0,866 & 1,155 \\
X2 & 0,797 & 1,254 \\
X3 & 0,706 & 1,416 \\
X4 & 0,724 & 1,382 \\
Y & 0,866 & 1,155 \\
\hline
\end{tabular}

Tabel 5 menunjukkan nilai tolerance lebih besar dari 0,10 dan nilai VIF kurang dari 10, maka dapat disimpulkan antar variabel bebas tidak terjadi multikolinearitas.

Tabel 6. Hasil Uji Homosedatisitas Data

\begin{tabular}{cc}
\hline Variabel & Sig \\
\hline $\mathrm{X} 1$ & 0,550 \\
$\mathrm{X} 2$ & 0,685 \\
$\mathrm{X} 3$ & 0,873 \\
$\mathrm{X} 4$ & 0,477 \\
\hline
\end{tabular}


Tabel 6 menjelaskan bahwa semua variabel bebas tidak terjadi heteroskedatisitas karena nilai signifikansi lebih dari 0,05 . Hal tersebut berarti bahwa data terbukti homogen, sehingga prasyarat homosedastisitas data telah terpenuhi.

\section{Hasil Analisis Data}

Hasil analisis regresi $\mathrm{X}_{1}$ terhadap $\mathrm{Y}$ diketahui nilai $\mathrm{t}_{\text {hitung }}=5,139$ dengan signifikansi 0,000 . Dari hasil tersebut diketahui bahwa $t_{\text {hitung }}$ $(5,139)<\mathrm{t}_{\text {tabel }}(-1,980)$; dan nilai signifikansi 0,000 lebih kecil dari 0,05. Berdasarkan hasil tersebut dapat disimpulkan menolak $\mathrm{H}_{0}$ dan menerima $\mathrm{H}_{\mathrm{a}}$. Diketahui nilai Standardized Coefficients Beta ( $\beta$ ) bernilai positif yaitu 0,338 . Hal tersebut menunjukkan bahwa persepsi siswa tentang kompetensi mengajar guru berpengaruh positif dan signifikan terhadap prestasi belajar teori kejuruan.

Hasil analisis regresi $\mathrm{X}_{2}$ terhadap $\mathrm{Y}$ diketahui nilai $t_{\text {hitung }}=2,950$ dengan signifikansi 0,004 . Dari hasil tersebut diketahui bahwa $t_{\text {hitung }}$ $(2,950)>\mathrm{t}_{\text {tabel }}(-1,980)$; dan nilai signifikansi 0,004 lebih kecil dari 0,05. Berdasarkan hasil tersebut dapat disimpulkan menolak $\mathrm{H}_{0}$ dan menerima $\mathrm{H}_{\mathrm{a}}$. Diketahui nilai Standardized Coefficients Beta $(\beta)$ bernilai positif yaitu 0,202 . Hal tersebut menunjukkan bahwa persepsi siswa tentang pola asuh orang tua berpengaruh positif dan signifikan terhadap prestasi belajar teori kejuruan.

Hasil analisis regresi $\mathrm{X}_{3}$ terhadap $\mathrm{Y}$ diketahui nilai $t_{\text {hitung }}=3,911$ dengan signifikansi 0,000 . Dari hasil tersebut diketahui bahwa $t_{\text {hitung }}$ $(3,911)>t_{\text {tabel }}(-1,980)$; dan nilai signifikansi 0,000 lebih kecil dari 0,05. Berdasarkan hasil tersebut dapat disimpulkan menolak $\mathrm{H}_{0}$ dan menerima $\mathrm{H}_{\mathrm{a}}$. Diketahui nilai Standardized Coefficients Beta ( $\beta$ ) bernilai positif yaitu 0,284 . Hal tersebut menunjukkan bahwa motivasi berprestasi siswa berpengaruh positif dan signifikan terhadap prestasi belajar teori kejuruan.

Hasil analisis regresi $\mathrm{X}_{4}$ terhadap $\mathrm{Y}$ diketahui nilai $\mathrm{t}_{\text {hitung }}=2,557$ dengan signifikansi 0,012 . Dari hasil tersebut diketahui bahwa $t_{\text {hitung }}$ $(2,557)>t_{\text {tabel }}(-1,980)$; dan nilai signifikansi 0,012 lebih kecil dari 0,05. Berdasarkan hasil tersebut dapat disimpulkan menolak $\mathrm{H}_{0}$ dan menerima $\mathrm{H}_{\mathrm{a}}$. Diketahui nilai Standardized Coefficients Beta ( $\beta$ ) bernilai positif yaitu 0,184. Hal tersebut menunjukkan bahwa persepsi siswa tentang kelengkapan sarana dan prasarana praktik berpengaruh positif dan signifikan terhadap prestasi belajar teori kejuruan.

Hasil analisis regresi $\mathrm{X}_{1} \mathrm{X}_{2} \mathrm{X}_{3} \mathrm{X}_{4}$ terhadap $\mathrm{Y}$ diketahui nilai $\mathrm{F}_{\text {hitung }}=34,437$ dengan signifikansi 0,000. Dari hasil tersebut diketahui bahwa $\mathrm{F}_{\text {hitung }}(34,437)>\mathrm{F}_{\text {tabel }}(2,691)$; dan nilai signifikansi 0,000 lebih kecil dari 0,05. Berdasarkan hasil tersebut disimpulkan bahwa menolak $\mathrm{H}_{0}$ dan menerima $\mathrm{H}_{\mathrm{a}}$. Diketahui nilai $\mathrm{R}$ bernilai positif yaitu 0,720 dan Adjusted $R$ Square $=0,503$. Sehingga dapat disimpulkan bahwa terdapat pengaruh yang positif dan signifikan persepsi siswa tentang kompetensi mengajar guru, pola asuh orang tua, motivasi berprestasi peserta didik, dan kelengkapan sarana dan prasarana praktik terhadap prestasi belajar teori kejuruan. Berdasarkan nilai Adjusted $R$ Square dapat diketahui bahwa keempat variabel bebas tersebut mampu menjelaskan sebesar $50,3 \%$ variasi pada variabel terikat yaitu prestasi belajar teori kejuruan; sedangkan 49,7\% dijelaskan oleh variabel lain yang tidak diteliti dengan persamaan regresi sebagai berikut:

$\mathrm{Y}=-85,636+0,266 \cdot \mathrm{X}_{1}+0,276 \cdot \mathrm{X}_{2}+0,265 \cdot \mathrm{X}_{3}$ $+0,370 ._{4}$

\section{SIMPULAN DAN SARAN}

\section{Simpulan}

Berdasarkan hasil analisis data dan pembahasan diambil beberapa kesimpulan sesuai rumusan masalah sebagai berikut:

Hasil analisis deskriptif menunjukkan persepsi siswa tentang kompetensi mengajar guru sangat tinggi; pola asuh orang tua rendah; motivasi berprestasi peserta didik rendah; kelengkapan sarana dan prasarana praktik sangat rendah; dan prestasi belajar teori kejuruan sangat rendah.

Hasil analisis regresi menunjukkan nilai $\beta$ $=0,338 ; \mathrm{t}_{\text {hitung }}=5,139$; dan signifikansi $=0,000$. Maka dapat disimpulkan bahwa terdapat pengaruh yang positif dan signifikan persepsi 
peserta didik tentang kompetensi mengajar guru terhadap prestasi belajar teori kejuruan.

Hasil analisis regresi menunjukkan nilai $\beta$ $=0,202 ; \mathrm{t}_{\text {hitung }}=2,950$; dan signifikansi $=0,004$. Maka dapat disimpulkan bahwa terdapat pengaruh yang positif dan signifikan persepsi siswa tentang pola asuh orang tua terhadap prestasi belajar teori kejuruan.

Hasil analisis regresi menunjukkan nilai $\beta=0,284 ; t_{\text {hitung }}=3,911 ;$ dan signifikansi $=0,000$. Maka dapat disimpulkan bahwa terdapat pengaruh yang positif dan signifikan motivasi berprestasi siswa terhadap prestasi belajar teori kejuruan.

Hasil analisis regresi menunjukkan nilai $\beta=0,184 ; t_{\text {hitung }}=2,557 ;$ dan signifikansi $=0,012$. Maka dapat disimpulkan bahwa terdapat pengaruh yang positif dan signifikan persepsi siswa tentang kelengkapan sarana dan prasarana praktik terhadap prestasi belajar teori kejuruan.

Hasil analisis regresi menunjukkan nilai $\mathrm{R}=0,720 ;$ Adjusted $R$ Square $=0,503$; nilai $\mathrm{F}_{\text {hitung }}=34,437$; dan signifikansi $=0,000$. Maka dapat disimpulkan bahwa terdapat pengaruh yang positif dan signifikan persepsi siswa tentang kompetensi mengajar guru, pola asuh orang tua, motivasi berprestasi peserta didik, dan kelengkapan sarana dan prasarana praktik secara bersama-sama terhadap prestasi belajar teori kejuruan dan sumbangan sebesar 50,3\%; sedangkan $49.7 \%$ sisanya dijelaskan oleh variabel lain yang tidak diteliti.

\section{Saran}

Hasil penelitian ini diharapkan dapat memberikan kontribusi pada mahasiswa lain yang ingin melakukan penelitian serupa, sekolah, Dinas Pendidikan, dan instansi terkait lain. Adapun saran yang dapat disampaikan dari hasil penelitian ini adalah:

Dinas Pendidikan dan sekolah perlu menambah kegiatan pengembangan kompetensi guru dalam mengajar terutama pemanfaatan teknologi informasi dan komunikasi, sehingga dapat membantu mempermudah menyampaikan materi ajar. Selain itu, perlu secara rutin mengadakan kegiatan workshop dan pelatihan terhadap guru untuk dapat meningkatkan skill kompetensi secara praktik maupun teori terkait dengan perkembangan ilmu pengetahuan baru pada bidang keahlian yang ditekuni.

Orang tua perlu lebih memperhatikan kondisi setiap anak, baik dari segi kebutuhan pemenuhan alat pembelajaran, kebebasan dalam berkreasi, perhatian, dan kasih sayang orang tua terhadap anak, sehingga anak tidak mencari perhatian dan kebutuhan yang diinginkan di luar rumah karena rawan terjadi penyalahgunaan. Orang tua perlu dalam kondisi tertentu bersikap demokratis terhadap anak untuk memberikan ruang pengembangan bakat dan minat untuk berkreasi dan bereksperimen pada bidang yang ditekuni.

Perlu perhatian dan peran aktif dari lingkungan sekitar siswa, mulai dari lingkungan keluarga, lingkungan sekolah, dan lingkungan pergaulan dalam upaya peningkatan kompetensi praktik dan teori dalam mempelajari materi pada bidang studi keahlian yang ditekuni. Lingkungan sekitar seperti keluarga dan sekolah sedikit banyak dapat memberikan kontribusi terhadap motivasi peserta didik untuk belajar dan berprestasi.

Perlu dilakukan penelitian yang lebih mendalam lagi terhadap beberap faktor baik secara internal maupun eksternal yang berpotensi dapat mempengaruhi kualitas prestasi belajar siswa. Lokasi dan jumlah sampel juga perlu diperluas dan diperbanyak untuk mendapatkan kesimpulan dan gambaran secara makro terhadap faktor-faktor yang mempengaruhi pencapaian prestasi belajar teori kejuruan.

\section{Daftar Pustaka}

Atkinson, J. W. (1980). Motivational effects in socalled tests of ability and educational echievement. Dalam Fyans, L. J., Jr. (Ed.), Achievement Motivation, Recent Trends in Theory and Research (pp. 9-21). New York: Springer Science+Business Media.

Bornstein, M. H. (2008). Positive parenting and positive chracteristics and values in children. Dalam M. Kerr., H. Stattin., R. C. M. E. Engels (Ed.), What Can Parents Do? New Insights into the 
Role of Parents in Adolescent Problem Behavior (pp. 259-284). England: John Wiley \& Sons, Ltd.

Briggs, A. R. J., \& Sommefeldt, D. (2002). Managing effective learning and teaching. London: Paul Chapman Publishing.

Catts, R., Falk, I., \& Wallace R. (2011). Vocational learning: Innovative theory and practice. New York: Springer Science+Business Media.

Isaac, S. \& Michael, W. B (1982). Handbook in research and evaluation: A collection of principles, methods, and strategies useful in the planning, design, and evaluation of studies in education and the behavioral sciences ( $2^{\text {nd }} e d$ ). San Diego: EDITS Publishers.

Cizek, G. J. (1997). Learning, achievement, and assessment: constructs at a crossroads. Dalam G. D. Phye (Ed.). Handbook of Classroom Assessment: Learning Achievement and Adjustment (pp. 2-32). United State: Academic Press.

Crocker, L., \& Algina, J. (2006). Introduction to classical and modern test theory. United States: Cengage Learning.

Brophy, J. (2004). Motivating student to learn $\left(2^{\text {nd }} e d\right)$. New Jersey: Lawrence Erlbaum Associates, Publishers.

Clifford, M. M. (1980). Effects of failure: alternative explanations and possible implications. Dalam Fyans, L. J., Jr. (Ed.). Achievement Motivation, Recent Trends in Theory and Research (pp. 9-21). New York: Springer Science+Business Media.

Darling, N. (Maret 1999). Parenting style and its correlates. Artikel EDO-PS-99-3. Diambil pada tanggal 27 Juli 2014, dari http://ecap.crc.illinois.edu/eecearchive/ digests/1999/darlin99.pdf

Erthman, G. I. (2009). Planning education facilities: What educators need to know $\left(3^{\text {ed }}\right)$. United Kingdom: Rowman \& Littlefield Education.
Fyans, L. J., Jr. (1980). Achievementmotivation: Recent trends in theory and research. New York: Springer Science+Businnes Media.

Riduwan (2011). Belajar mudah penelitian untuk guru-karyawan dan peneliti pemula. Bandung: Alfabeta.

Grolnick, W. S., Friendly, R. W., \& Bellas, V. M. (2009). Parenting and children's motivation at school. Dalam K. R. Wentzel \& A. Wigfield (Ed.), Handbook of Motivation at School (pp. 279-300): New York: Routledge Falmer.

Allen, M. J., \& Yen, W. M. (1979). Introduction to measurement theory. California: Wadsworth, Inc.

Hewitt, D. (2008). Understanding effective learning: strategies for the classroom. Berkshire: Open University Press.

Hill, K. T. (1980). Motivation, evaluation, and educational testing policy. Dalam Fyans, L. J., Jr. (Ed.). Achievement Motivation, Recent Trends in Theory and Research (pp. 34-95). New York: Springer Science+Business Media.

Klusmann, U. (2013). Occupational SelfRegulation. Dalam Kunter, et. al (Ed.), Cognitive Activation in the Mathematics Classroom and Professional Competence of Teachers: Result from the COACTIV Project (pp. 291-310).. New York: Springer Science+Business Media.

Koopmans, L. et.al. (2011). Conceptual frameworks of individual work performance, a systematic review. [Versi electronik]. American College of Occupational and Environmental Medicine, 53, 856-866.

Krause, P. H., \& Dailey, T. M. (2009). Handbook of parenting: Styles, stresses and strategies. New York: Nova Science Publishers, Inc.

Liu, M,-T., \& Yu, P,-T. (2011). Aberrant learning achievement detection based on person-fit statistics in personalized 
e-learning system. [Versi electronik]. Educational Technology \& Society, 14 (1). 107-120.

Marzano, R. J, \& Marzano, J. S. (2003). The key to classroom management. [Versi electronik]. Educational Leadership, 61 (1). 6-13.

Marzano, R. J., \& Brown, J. L. (2009). A handbook for the art and science of teaching. Alexandria: Association for Supervision and Curriculum Development.

Maslow, A. M. (1970). Motivation and personality. New York: Harper \& Row Publishers, Inc.

Mulyasa, E. (2002). Manajemen berbasis sekolah: konsep, strategi, dan implementasi. Bandung: P.T. Remaja Rosdakarya.

Nasrudin, A. M., \& Khuan, S. L. (2007). Organizational Justice as an antecedent of job performance [Versi electronik]. Gajah Mada International Journal of Business, 335-353.

Norton, L. S. (2009). Action research in teaching \& Learning: A practical guide to conducting pedagogical research in universities. London \& New York: Routledge Falmer.

P21 Framework Definitions. (2009). The Partnership for 21st Century Skills, Diambil tanggal 1 Juli 2014, dari http:// www.p21.org/our-work/p21-framework

Pang, J. S. (2010). The achievement motive: a review of theory and assessment of $n$ achievement, hope of success, and fear of failure. Dalam. O. C. Schultheiss, \& J. C. Brunstein (Ed.), Implicit Motives (pp. 30-70). New York: Oxford University Press. Inc.

Pavlova, M. (2009). Technology and vocational education for sustainable development: Empowering individuals fot the future. Bonn: Springer Science+Business Media.
Pikiran Rakyat (2014) Mendikbud: Masih banyak masalh dalam pendidikan pelatihan kejuruan. Diakses tanggal 1 Juli 2014, dari http://www.pikiranrakyat.com/node/276264.

Ramaekers, S. \& Suissa, J. (2012). The claims of parenting: Reasons, responsibility, and society. Dordrecht: Springer Science+Business Media.

Republik Indonesia .(2006). UndangUndang RI Nomor 23, Tahun 2006, Tentang Standar Kompetensi Lulusan untuk Satuan Pendidikan Dasar dan Menengah.

Republik Indonesia .(2008). Peraturan Menteri Pendidikan Nasional RI Nomor 28, Tahun 2008, tentang Standar Kompetensi Kejuruan Sekolah Menengah Kejuruan (SMK)/Madrasah Aliyah Kejuruan (MAK).

Rojewski, J.W.(2009). A conceptual framework of technical and vocational education and training. Dalam R. Maclean \& D. N. Wilson (Ed.), International Handbook of Education for the Changing World for Work: Bridging Academic and Vocational Learning (pp. 19-40). Bonn: Springer Science+Business Media.

Slameto. (2003). Belajar dan faktor-faktor yang mempengaruhinya. Jakarta: PT. Rineka Cipta.

Rothrauff, T. C., Cooney, T. M., \& An, J. S. (2009). Remembered parenting styles and adjustment in middle and late adulthood [Versi electronik]. The Journals of Gerontology, 64B(1). 137146.

Sanjaya, W. (2006). Stretegi pembelajaran berorientasi standar proses pendidikan. Jakarta: Kencana Prenada Media.

Smith, A. (1998). Accelerated learning in practice, brain-based methods for accelerating motivation and achievement. London: Network Educational Press Ltd. 
Sudira, P. (2012). Filosofi \& Teori Pendidikan Vokasi dan Kejuruan. Yogyakarta: UNY Press.

Vazquez, C. I. (2004). Parenting with priode latino style: How to help your child cherish your cultural values and succed in today's world. Australia: HarperCollins e-books.
Wigfield, A. \& Eccles, J. S. (2002). Development of achievement motivation. United States: Academic Press. 